\section{Willingness To Pay}

Helga Peter

Marburg, Deutschland

\section{Synonyme}

WTP; Zahlungsbereitschaft

\section{Definition}

Durch Befragung des Betroffenen ermittelte Höhe des Geldbetrages, den er aufzuwenden bereit wäre, um eine medizinische Leistung zu erhalten.

Siehe auch $\triangleright$,Pharmakoökonomie“. 